\title{
PEMANFAATAN LINGKUNGAN SEBAGAI SUMBER BELAJAR ANAK DI TK ALIFIA SAMARINDA
}

\author{
Andi Aslindah \\ Universitas Widya Gama Mahakam Samarinda \\ aslindah.andirezky@yahoo.com
}

\begin{abstract}
This research aims to know how teachers understand and awareness about the importance of utilizing the environment as a learning resource and to know how the teacher's strategy in implementing the environment as a medium and learning resources for the children in the Kindergarten Alifia. This study uses a qualitative method approach with a type of case study study. Case study research, concentrating intensively on one particular object that learns it as a case. From the results of the study get that: 1) teacher understanding of the importance of using the environment as a source of learning in early childhood is good enough. 2) before implementing the learning process that utilizes the environment as a learning resource, teachers need to prepare from the stage of activity planning, implementation of activities and follow up as an evaluation of the activities undertaken. 3) The constraints most often experienced by teachers during the implementation of learning by utilizing the environment as a learning resource is the time it takes to be longer and companion children who sometimes do not compare to the number of children.
\end{abstract}

Keywords: environmental utilization, learning resources, early childhood

\section{Pendahuluan}

Pendahuluan mencakup latar belakang atas isu atau permasalahan serta urgensi, rasionalisasi kegiatan (penelitian) dan ulasan literatur. Tujuan kegiatan dan rencana pemecahan masalah disajikan dalam bagian ini. (Times New Roman 12, 1 spasi, setiap paragraf $1 \mathrm{tab})$.

Pembelajaran merupakan suatu proses yang sistematik yang terdiri dari banyak komponen. Salah satunya adalah sumber belajar. Sumber belajar merupakan suatu unsur yang sangat penting peranannya dalam menentukan efektif dan efisiennya pencapaian tujuan pembelajaran dalam proses belajar mengajar. Ada yang beranggapan bahwa sumber belajar itu adalah guru dan buku paket saja. Padahal banyak sekali sumber belajar yang ada di sekitar sekolah, rumah maupun di masyarakat. Hanya saja kita yang belum kreatif memanfaatkan sumber belajar tersebut dengan maksimal.

Dunia pendidikan sebenarnya tidak bisa dipisahkan dengan lingkungan. Lingkungan merupakan sumber belajar yang vital. Bilamana lingkungan dijadikan sebagai objek belajar dalam proses pembelajaran maka dapat memberikan pengalaman secara nyata dan langsung kepada siswa, terutama bagi anak usia dini pemanfaatan lingkungan sebagai objek belajar sangat penting mengingat perkembangan mereka masih dalam tahap berpikir dari benda yang konkret. Oleh karena itu anak memang sangat perlu dirangsang untuk berpikir dengan metode pembelajaran yang menggunakan benda nyata. Peran guru sebagai fasilitator dalam pelaksanaan pendidikan terutama untuk anak usia dini harus mampu memberikan kemudahan kepada anak untuk mempelajari berbagai hal yang terdapat dalam lingkungannya.

Menurut Nasution, cara memanfaatkan lingkungan sebagai sumber belajar yaitu dengan dua cara: (1) dengan membawa sumber-sumber dari lingkungan ke dalam kelas, dan (2) dengan membawa siswa ke lingkungan. Agar penggunaan lingkungan sebagai sumber belajar berjalan efektif maka perlu dilakukan perencanaan, pelaksanaan, dan evaluasi serta tindak lanjutnya. Dengan berbekal kreatifitas, guru dapat memanfaatkan lingkungan sebagai sumber belajar tidak perlu harus pergi jauh dengan biaya mahal, lingkungan yang berdekatan dengan sekolah dan rumah pun dapat dioptimalkan menjadi sumber belajar yang sangat bernilai bagi kepentingan belajar anak. 
Berdasarkan uraian di atas maka penulis tertarik untuk melakukan penelitian di TK Alifia terkait dengan upaya lembaga ini dalam memanfaatkan lingkungan sebagai sumber belajar bagi peserta didiknya. Mulai dari tahap perencanaan, pelaksanaan, evaluasi dan tindak lanjut dari kegiatan pembelajaran yang menjadikan lingkungan sebagai sumber belajar. Karena dari hasil observasi penulis di TK Alifia didapatkan hasil wawancara dengan guru-guru di TK Alifia yang menyatakan bahwa di lembaga mereka sudah sering membawa anak untuk kunjungan ke kebun-kebun sayur dan ke instansi-instansi seperti rumah sakit, kantor polisi, pemadam kebakaran, kantor pos untuk mengenalkan anak-anak tentang macam-macam profesi.Selain itu anak-anak sering juga diberikan kegiatan-kegiatan outdoor.

Penelitian ini bertujuan untuk mengetahui pemahaman guru tentang peran lingkungan sebagai sumber belajar bagi anak usia dini, mengetahui strategi guru dalam memanfaatkan lingkungan sebagai sumber belajar serta mengetahui kendala-kendala yang dihadapi guru dalam memanfaatkan lingkungan sebagai sumber belajar anak usai dini di TK Alifia Samarinda.

\section{Metode Penelitian}

Penelitian ini menggunakan pendekatan metode kualitatif dengan jenis penelitian studi kasus (Case Study). Dalam penelitian ini yang menjadi subjek penelitian adalah anak didik dan guru TK Alifia, sedangkan yang menjadi objek penelitian yaitu strategi guru dalam memanfaatkan lingkungan sebagai sumber belajar. Pada penelitian ini peneliti menggunakan teknik pengumpulan data dengan cara observasi, dokumentasi, dan wawancara. Analisis data dimulai dengan melakukan wawancara mendalam dengan informan kunci, yaitu seseorang yang benar-benar memahami dan mengetahui situasi obyek penelitian. Dalam penelitian ini yang sebagai informan kuncinya yaitu guru kelompok A dan B. Setelah peneliti menulis hasil wawancara tersebut kedalam transkrip, selanjutnya peneliti harus membaca secara cermat untuk kemudian dilakukan reduksi data. Peneliti membuat reduksi data dengan cara membuat abstraksi, yaitu mengambil dan mencatat informasi-informasi yang bermanfaat sesuai dengan konteks penelitian atau mengabaikan kata-kata yang tidak perlu sehingga didapatkan inti kalimatnya saja, tetapi bahasanya sesuai dengan bahasa informan.

\section{Hasil Penelitian dan Pembahasan Hasil Penelitian}

Berdasarkan hasil observasi dan wawancara dengan guru-guru di TK Alifia peneliti mendapatkan gambaran bahwa pemahaman guru tentang pentingnya menggunakan lingkungan sebagai sumber belajar pada anak usia dini cukup baik. Terlihat selama observasi proses kegiatan pembelajarannya tidak momoton dilaksanakan di dalam kelas saja akan tetapi anak-anak banyak dibawa aktivitas keluar kelas/sekolah (Outdoor). Dengan adanya aktivitas-aktivitas yang dilaksanakan diluar kelas (outdoor) maka semua aspk perkembangan anak dapat ditingkatkan. Hal ini dapat terjadi karena aktivitas outdoor melibatkan multiaspek perkembngan anak. Termasuk perkembangan fisik, keterampilan sosial, pengetahuan budaya, perkembangan intelektual dan emosionalnya.

Dari hasil wawancara dengan guru peneliti juga mendapatkan gambaran tentang srategi guru dalam mempersiapkan kegiatan belajar dengan memanfaatkan lingkungan sebagai sumber belajar yaitu sebelum melaksanakan pembelajaran sangat perlu perencanaan yang matang, dari awal harus ditentukan tujuan apa yag diharapkan akan dicapai oleh anak, objek apa yang sesuai dengan tema , berapa waktu yang diperlukan dalam pelaksanaan, merumuskan cara belajar anak kemudian menetukan tindak lanjut apa yang sebaiknya diberikan kepada anak setelah mengikuti kegiatan pembelajaran di luar kelas dengan menggunakan lingkungan sebagai media atau sumber belajar. Selain itu juga harus mempersiapkan surat perizinan bilamana kunjungan dilakukan ke instansi-instansi.seperti kantor polisi, kantos pos, dan sebagainya. Manfaat dari perizinan ini adalah salah satunya untuk mengefisienkan waktu karena pada saat 
tiba di lokasi sumber belajar maka bisa langsung diterima oleh pihak yang berwenang instansi tersebut. Selain itu bila terjadi hal-hal yang tidak diinginkan akan lebih mudah dimaklumi oleh pihak orang tua/wali anak maupun sekolah.

Dari sekian banyaknya manfaat yang dapat diperoleh dari pemanfaatan lingkungan sebagai sumber belajar anak usia dini juga terdapat kendala-kendala yang ditemukan selama proses pelaksanaan. Hasil wawancara dari guru, kendala yang paling sering didapatkan adalah terkadang tidak semua anak bisa fokus pada objek yang harus diamatinya, lebih banyak main-mainnya. Apalagi kalo guru pendamping kurang pada saat pelaksanaan,. Makanya terkadang pihak sekolah melibatkan orang tua/wali siswa untuk ikut mendampingi bila ada kegiatan pembelajaran diluar kelas atau kunjungan keluar dari lingkungan sekolah.. Kendala lain yang biasa ditemukan bila memanfaatkan lingkungan sebagai sumber belajar adalah ketersediaan waktu yang terbatas. Terkadang alokasi waktu tidak sesuai dengan perencanaan.

\section{Pembahasan}

\section{a. Peran Lingkungan Sebagai Sumber Belajar Bagi Anak Usia Dini}

Lingkungan yang ada di sekitar anak meupakan salah satu sumber belajar yang dapat dioptimalkan dalam pencapaian proses dan hasil pendidikan yang berkualitas bagi anak usia dini. Karena sangat banyak nilai dan manfaat yang dapat didapatkan dari lingkungan sebagai sumber dan media belajar. Dalam kurikulum Pendidikan Anak Usia Dini hampir semua tema kegiatan dapat dipelajari dari lingkungan.

Memanfaatkan lingkungan sekitar dengan membawa anak-anak untuk mengamati lingkungan akan menambah keseimbangan dalam kegiatan belajar. Artinya belajar tidak hanya terjadi di ruangan kelas namun juga di luar ruangan kelas dalam hal ini lingkungan sebagai sumber belajar yang sangat berpengaruh terhadap perkembangan fisik, keterampilan sosial, dan budaya, perkembangan emosional serta intelektual.

a) Peran lingkungan sebagai sumber belajar bagi perkembangan fisik anak usia dini :
Lingkungan mempunyai peranan yang sangat besar dalam merangsang pertumbuhan fisik anak, terutama dalam mengembangkan otot-ototnya. Karena belajar melalui lingkungan anak akan memiliki kesempatan untuk menggerakan tubuhnya secara alami dan tidak terbatas seperti berlari, melompat maupun berkejaran dengan teman-temannya. Dengan pemanfaatan lingukngan sebagai sarana belajar bagi anak maka anak-anak akan banyak belajar dan menjadi tahu bagaimana tubuh mereka bekerja dan merasakan bagaimana rasanya berayunayun, berguling, melangkak melalui terowongan ataupun memanjat pohonpohon tertentu.

b) Peran lingkungan sebagai sumber belajar bagi perkembangan sosial emosional anak : Anak belajar melalui lingkungan secara alami akan mendorong anak untuk berinteraksi dengan teman sebayanya ataupun dengan orang-orang dewasa. Karena pada saat anak mengamati suatu objek-objek tertentu yang ada di lingkungan pasti dia ingin berbagi cerita tentang hasil penemuannya kepada teman sebayanya atau orang lain ataupun bertanya pada orang dewasa tentang hal yang berkaitan dengan penemuannya. Mereka akan mendekati anak yang lain supaya penemuannya diketahui oleh teman-temannya sehingga terjadilah proses interaksi yang harmonis bagi mereka. Selain itu lingkungan juga pada umumnya dapat memberikan tantangan yang dapat dilalui oleh anak-anak. Pemanfaatan lingkungan akan memungkinkan anak untuk mengembangkan rasa percaya diri yang positif. Misalnya bila anak diajak ke sebuah taman yang terdapat beberapa pohon yang memungkinkan untuk mereka panjat. Dengan memanjat pohon tersebut anak mengembangkan aspek keberaniannya sebagai bagian dari pengembangan aspek emosinya.

c) Peran lingkungan sebagai sumber belajar bagi perkembangan kognitif anak : Melalui lingkungan anak-anak akan belajar berinteraksi langsung dengan makhluk lain 
maupun benda yang ada di lingkungan. Guru dalam mendampingi anak belajar berpeluang untuk menguatkan kembali konsep-konsep tertentu seperti bentuk, warna, angka ataupun ukuran secara alami.

d) Peran lingkungan sebagai sumber belajar bagi perkembangan Agama dan Moral anak : Anak belajar dari lingkungan merupakan proses pembentukan kepribadian dan karakter anak. Anak dibawa belajar ke lingkungan mengamati dan mensyukuri segala ciptaan Allah yang sangat beragam. Sehingga anak dapat ditanamkan nilai karakter bagaimana memupuk kecintaan dan kepedulian kita dalam menjaga kelestarian lingkungan.

\section{b. Strategi Guru Dalam Memanfaatkan Lingkungan Sebagai Sumber Belajar Bagi Anak Usai Dini}

Sebelum melaksanakan proses pembelajaran, sebaiknya perencanaan harus diatur dan ditata secara matang agar dalam pelaksanaannya nanti dapat mencapai hasil belajar yang optimal. Begitupun halnya dalam merencanakan lingkungan sebagai sumber belajar. Menurut Zaman (2012), ada tiga langkah yang perlu diperhatikan dalam memanfaatkan lingkungan sebagai sumber belajar, yaitu antara lain :

1) Langkah Perencanaan : Perencanaan merupakan bagian yang yang pertama dan sangat penting di perhatikan dalam proses pembelajaran. Apabila perencanaan disusun secara matang maka tujuan pembelajaran yang ditentukan akan dicapai dengan optimal. Hal-hal yang perlu dilakukan dalam merencanakan pemanfaatan lingkungan sebagai sumber belajar, anatar lain : a) Menentukan tujuan yang harus dicapai oleh anak, b) Menentukan obyek lingkungan yang akan dikunjungi atau di pelajari. Misalkan di lingkungan sekitar sekolah, kebun sayur, peternakan atau instansi-instansi seperti kantor pos, kantos polisi dan sebagainya. c) Guru perlu mempersiapkan surat perizinan jika memang diperlukan. Misalkan rencana berkunjung ke kantor pos atau di instansi lainnya maka perlu membuat dan mengirimkan surat permohonan mengunjungi objek tersebut agar instansi tersebut bisa mempersiapkannya. d) Menentukan waktu pelaksanaan kegiatan, e) Merumuskan cara-cara belajar anak dalam memanfaatkan lingkungan sebagai sumber belajar. Misalnya anak-anak diharapkan dapat mengamati suatu proses dan bertanya kemudian menceritakannya kembali dan sebagainya, f) Menyiapkan hal-hal yang bersifat teknis. Misalkan persiapan teknis untuk kegiatan belajar seperti tata tertib di perjalanan ataupun di tempat tujuan/objek lingkungan yang dikunjungi, perlengkapan belajar yang perlu dibawa, kamera untuk dokumentasi, transportasi yang akan digunakan, biaya, bekal yang perlu dibawa maupun perlengkapan P3K.

2) Langkah Pelaksanaan : Pada langkah ini pelaksanaan kegiatan belajar di tempat tujuan yang sesuai dengan perencanaan yang sudah ditetapkan dari awal. Bilamana kegiatan yang dilaksanakan merupakan kegiatan karya wisata atau survey pada suatu objek tertentu maka biasanya kegiatan ini diawali dengan penjelasan dari karyawan atau petugas mengenai objek yang dikunjunginya. Sedangkan apabila objek yang dikunjungi atau dipelajari bersifat bebas dan tidak memerlukan petugas yang khusus untuk mendampingi seperti kegiatan jalan-jalan di sekitar lingkungan sekolah. Dalam pelaksanaan pembelajaran dengan pemanfaatan lingkungan sebaiknya guru selalu mendampingi anak. Hal-hal yang perlu diperhatikan oleh guru dalam mendampingi anak belajar di luar lingkungan kelas/sekolah : a) Mengamati apa yang menarik bagi anak,. b) Memberikan pertanyaan-pertanyaan terbuka kepada anak c) Menggunakan kosa kata yang beragam untuk menjelaskan hal-hal baru d) Mencoba bersikap lebih ingin tahu

3) Langkah Tindak Lanjut : Langkah tindak lanjut merupakan langkah yang terakhir, dimana semua kegiatan yang telah dilaksanakan didiskusikan di dalam kelas oleh guru dan anak. Guru memberikan pertanyaaan kepada setiap anak secara bergiliran kemudian guru dengan penuh kesabaran harus memberikan kesempatan kepada setiap anak untuk mengutarakan atau menceritakan segala pengalaman belajar yang telah didapatkannya selama kunjungan di luar kelas. Selain masing-masing anak diberi tugas 
untuk menceriatakan kembali pengalaman belajarnya di lingkungan objek belajar, bisa juga dilanjutkan dengan tugas lain yaitu mengingat kembali objek yang sudah diamatinya selama di lapangan kemudian anak diharapkan menggambarkan objek tersebut di buku gambar.

\section{c. Kendala guru dalam memanfaatkan lingkungan sebagai sumber belajar anak usai dini}

Pemanfaatan lingkungan sebagai sumber belajar memiliki arti yang sangat penting dalam proses pembelajaran khususnya dalam pembelajaran anak usia dini. Karena lingkungan mudah di jangkau, tidak mesti mencari objek yang jauh cukup yang disekitar anak saja. Namun dibalik banyaknya manfaat dari penggunaan lingkungan sebagai sumber dan media belajar dalam proses pembelajaran siswa khususnya bagi anak usia dini terdapat juga kendala-kendala yang dihadapi oleh guru. Berdasarkan dari hasil wawancara dengan guru dalam penelitian ini kendala yang paling sering dialami oleh guru pada saat pelaksanaan pembelajaran dengan pemanfaatan lingkungan sebagai sumber belajar adalah waktu yang dibutuhkan harus lebih lama dan pendamping anak juga harus sesuai dengan jumlah anak agar anak selama berkegiatan bisa terkontrol dengan baik. Sehingga tujuan pembelajaran dapat tercapai.

\section{Kesimpulan}

Pendidik Anak usia dini sebagai fasilitator dalam melaksanakan proses pembelajaran di PAUD dituntut untuk selalu kreatif dan inovatif dalam memanfaatkan lingkungan sebagai sumber belajar. Pemanfaatan lingkungan sebagai sumber belajar sangat baik diterapkan dalam pembelajaran anak usia dini karena lingkungan menyediakan berbagai pengalaman belajar yang sangat banyak manfaatnya. Anak dapat belajar dengan cara menyatu pada lingkungan, anak tidak saja belajar teori melainkan dapat mengamati dan merasakan langsung sehingga memberikan pengalaman nyata bagi anak. Namun sebelum melaksanakan proses pembelajaran yang memanfaatkan lingkungan sebagai sumber belajar, sebaiknya perencanaan harus diatur dan ditata secara matang agar dalam pelaksanaannya nanti dapat mencapai hasil belajar yang optimal. Guru perlu mempersiapkan mulai dari tahap perencanaan kegiatan, pelaksanaan kegiatan dan tidak lanjut sebagai evaluasi dari kegiatan yang dilaksanakan.

\section{Daftar Pustaka}

Asnawir dan Basyaruddin Usman. 2012.Media Pembelajaran. Jakarta: Ciputat Pers

Farida,Ana. et.al.2012. Sekolah yang Menyenangkan.Bandung: Nuansa Cendekia

Badru Zaman, dkk. 2012. Media dan Sumber Belajar. Jakarta: Universitas Terbuka.

Hamalik, Oemar. 2012.Kurikulum dan Pembelajaran. Bandung: Pena Grafika

Hasan Kasim dkk. 1985. "Pemanfaatan Lingkungan Sebagai Sumber Belajar Ilmu Pengetahuan Sosial Pada Sekolah Menengah Umum Tingkat Pertama di Kotamadya Banda Aceh". Jurnal Ilmu Pendidikan

Mariyana,Rita. et.al.2010.Pengelolaan

Lingkungan Belajar. Jakarta: Kencana.

Muhammad Efendi (2013). Lingkungan Sebagai Media Pembelajaran. Diunduh di http://efendi08.blogspot.co.id/2013/0 3/lingkungan-sebagai-mediapembelajaran.html pada tanggal 21 Maret 2016.

Musfiqon. 2012. Pengembangan Media dan Sumber Pembelajaran. Jakarta: Prestasi Pustaka Raya

Pristiadi Utomo (2011). Pemanfaatan Lingkungan sebagai Sumber Belajar Anak Usia Dini. Di unduh di https://ilmuwanmuda.wordpress.com /pemanfaatan-lingkungan-sebagaisumber-belajar-untuk-anak-usiadini/pada tanggal 21 Januari 2020

Rohani, Ahmad. 2004. Pengelolaan Pengajaran. Jakarta: PT Rineka Cipta

Ruswandi, Uus dan Badruddin. 2008. Media Pembelajaran.Bandung: $\quad \mathrm{CV}$ Insan Mandiri 
Sofia Hartati. (2005). Perkembangan Belajar Pada Anak Usia Dini. Jakarta: Depdiknas.

Sri Winarni. (2012). Lingkungan sebagai Sumber Belajar. Di unduh di http://diarywiens.blogspot.co.id/201 2/09/lingkungan-sebagai-sumberbelajar 11.html pada tanggal 22 JAnuari 2020

Syah, Muhibbin. 2010. Psikologi Pendidikan.Bandung: PT Remaja Rosdakarya 